\title{
Color stability of denture acrylic base after cleaning with rosella flower extract toothpaste
}

\author{
Mohammad Dharma Utama, Eri Hendra Jubhari, Bahruddin Thalib, Ike Damayanti Habar, Irfany \\ Department of Prosthodontics \\ Faculty of Dentistry, Hasanuddin University \\ Makassar, Indonesia \\ Correspondence author: Mohammad Dharma Utama, email: mohdharmautama.umi@gmail.com
}

\begin{abstract}
Background: The efficacy of rosella flowers as an antibacterial contains anthocyanin pigment which acts as an antioxidant, vitamins and minerals that are useful for the body so it needs to develop products other than drinks and food; one of them as herbal disinfectant for complete denture acrylic base. Objective: To determine the color stability of the complete denture base after cleaning with various concentrations of rosella flower extract. Method: This time series study with pre and post with control group design was carried out using 5 complete dentures cleaned with rosella flower extract toothpaste with a concentration of $2.5 \%, 5 \%, 10 \%$ and control, and assessed its color on the surface of the polished and intaglio surface. The value is processed into the formula $\Delta E^{*} a b=\left[\left(\Delta L^{*}\right) 2+\left(\Delta a^{*}\right) 2+\left(\Delta b^{*}\right) 2\right] 1 / 2$ then analyzed using the Kolmorogrov test and t-test. Result: Rosella flower extract toothpaste at concentrations of $2.5 \%, 5 \%$, and $10 \%$ did not show significant differences in color changes $(p>0.05)$. Conclusion: There were no significant differences in color changes at all concentrations after the acrylic base was cleaned with rosella flower extract.
\end{abstract}

Keywords: toothpaste, rosella flower extract, complete denture, discoloration

\section{INTRODUCTION}

Denture is an appliance to replace the surface of mastication and the surrounding structures of the upper and lower jaws. Denture material that is widely used in Indonesia is acrylic. $^{1-3}$

Two disadvantages of acrylic are high porosity and surface roughness so that the surface of the denture base that is not polished that is the part that faces the supporting tissue is more easily attached to the rest of food. If the base is not cleaned adequately it will become a place for microbes develop. ${ }^{4}$

Maintenance of denture cleanliness can be performed using denture cleaning agents. The use of natural ingredients in the health world tends to increase from year to year, included in the field of dentistry. The advantage of natural ingredients is the minimal side effects or safe for the body. Rosella is one of the natural ingredients used as drinks, food and medicine for the body. The efficacy of this flower is as an antibacterial, contains anthocyanin pigment which acts as an antioxidant, vitamins and minerals that are useful for the body. Knowing the many benefits of rosella, it is necessary to develop other products besides drinks and food, that is rosella flower extract which can function as an herbal disinfectant for acrylic dentures. ${ }^{5,6}$ The dark pink color of rosella flowers might affect the color of acrylic dentures, because this material can absorb liquid.
The aim of this article is to obtain data regarding the color stability of the acrylic base of removable denture after cleaning with extract of rosella flower as toothpaste.

\section{METHOD}

This time series study was design as pre and post with control, and in situ. The sample size was 20 of 5 samples for each concentration. The population was patients who attended the Clinic of Prosthodontics at Hasanuddin University, Makassar.

The samples are parts of the population that meets the inclusion and exclusion criteria. Inclusion criteria are patients who use full denture shortly after insertion, agrees to participate in this study, the patient is willing to not consume food and drinks that can affect the color of dentures, such as carbonated drinks; while exclusion criteria were patients using metal frame full denture, patients using partial denture flexidenture, patients using fixed dentures, and patients suffering from denture stomatitis, Candida albicans, and HIV-AIDS.

The toothpaste of rosella flower is maked by extracting it at concentrations of $2.5 \%, 5 \%$, $10 \%$ and non-rosella extract as control group; the toothpaste was made in the Laboratory of Pharmaceutical, Hasanuddin University. Before brushing using this rosella flower extract paste on acrylic denture, the sample was photographed and the $L^{*}, a^{*}, b$ * values were calculated with the CIELab system using the 
Adobe Photoshop® program. The same measurement is also carried out on the sample after the denture brushed to see the color changing.

The data were collected and analyzed by the Kolmogorov Smirnov test to know the data normality and then tested by independent t-test with a significance level of 0.05 .

\section{RESULT}

Based on this study, it was obtained statistical data showing color changes from the first week to the fourth week after brushing the denture.

Table 1 Mean data of color changing of denture base after brushing with extract of rosella flower at all concentrations in the first to fourth week.

\begin{tabular}{ccccc}
\hline \multirow{2}{*}{ Types } & \multicolumn{4}{c}{ Mean $\left(\mathrm{cm}^{-1}\right)$} \\
\cline { 2 - 5 } & Week I & Week II & Week III & Week IV \\
\hline Extract & 1.76 & 1,82 & 1,86 & 1,63 \\
\hline
\end{tabular}

Thet-testat each concentration for a month (Table 2) on the polished surface shows that after the use of rosella flower extract and control for a month showed insignificant color changes both in the first week to the fourth week; $p$-value more than 0.05).

\section{DISCUSSION}

This study using rosella flower extract as the denture cleanser. This formula was prepared in several concentrations, namely $2.5 \%, 5 \%$, and $10 \%$. This statement is consistent with Maruapey ${ }^{7}$ study which showed effectivity of rosella flower extraxt in inhibiting plaque formation, inhibiting the growth of bacterial colonies and Candida albicans colonies in acrylic resin dentures that were highest cleaned or brushed with rosella flower denture cleaning extract at a concentration of $10 \%$; $p$-value less than 0.05 ), and lowest in extracts with a concentration of $2.5 \%$; $p$-value was less than 0.05$)$. The active ingredient of rosella is flavonoid.

Table 2 Data of color changing on the polished surface at each concentration (t-test).

\begin{tabular}{lccccc}
\hline \multirow{2}{*}{ Polished surface } & \multirow{2}{*}{ Times } & \multicolumn{3}{c}{ Mean $\left(\mathrm{cm}^{-1}\right)$} & \multirow{2}{*}{ p-value } \\
\cline { 2 - 5 } & Week 1-2 & Before & After & difference & \\
\cline { 1 - 5 } Toothpaste of extract of & Week 1-3 & 1.25 & 0.68 & 0.56 & 0.178 \\
rosella flower 2.5\% & Week 1-4 & 1.25 & 0.96 & 0.28 & 0.224 \\
\multirow{2}{*}{ Toothpaste of extract of } & Week 1-2 & 1.51 & 1.25 & 0.00 & 1.000 \\
\cline { 2 - 5 } rosella flower 5\% & Week 1-3 & 1.51 & 1.81 & 0.10 & 0.595 \\
\multirow{2}{*}{ Toothpaste of extract of } & Week 1-4 & 1.51 & 1.29 & -0.29 & 0.406 \\
rosella flower 10\% & Week 1-2 & 2.39 & 2.12 & 0.22 & 0.100 \\
\hline \multirow{2}{*}{ Control } & Week 1-3 & 2.39 & 2.51 & -0.12 & 0.532 \\
& Week 1-4 & 2.39 & 2.21 & 0.18 & 0.764 \\
& Week 1-2 & 1.31 & 1.31 & 0.00 & 1.000 \\
\hline & Week 1-3 & 1.31 & 1.31 & 0.00 & 1.000 \\
& Week 1-4 & 1.31 & 1.31 & 0.00 & 1.000 \\
\hline
\end{tabular}

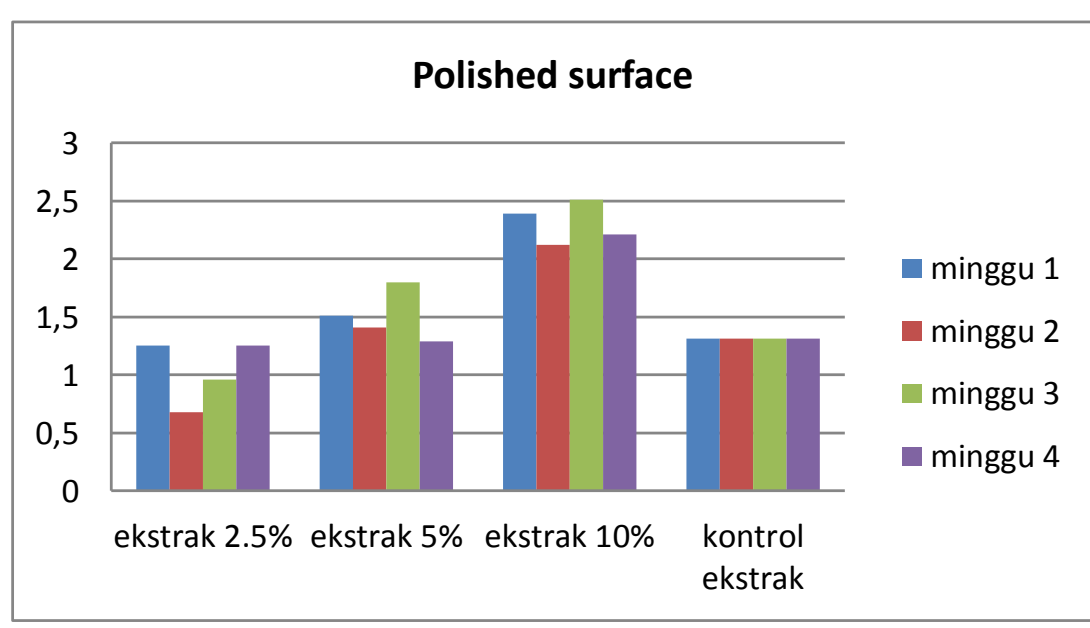

Figure 1 Color changes on polished surface in the $1^{\text {st }}-4^{\text {th }}$ week using toothpaste of extract of rosella flower paste at concentrations of $2.5 \%, 5 \%$, $10 \%$, and control. 
Table 3 Color changes on intaglio surfaces at each concentration (t-test)

\begin{tabular}{lccccc}
\hline \multirow{2}{*}{ Polished surface } & \multirow{2}{*}{ Times } & \multicolumn{3}{c}{ Mean $\left(\mathrm{cm}^{-1}\right)$} & \multirow{2}{*}{$\mathrm{P}$} \\
\cline { 3 - 5 } & & Before & After & Difference & \\
\hline \multirow{2}{*}{ Toothpaste of extract of } & Week 1-2 & 1.74 & 1.59 & 0.15 & 0.515 \\
rosella flower 2.5\% & Week 1-3 & 1.74 & 1.13 & 0.61 & 0.127 \\
& Week 1-4 & 1.74 & 1.51 & 0.23 & 0.228 \\
\hline \multirow{2}{*}{ Toothpaste of extract of } & Week 1-2 & 2.20 & 2.39 & -0.19 & 0.127 \\
rosella flower 5\% & Week 1-3 & 2.20 & 2.43 & -0.23 & 0.466 \\
& Week 1-4 & 2.20 & 2.05 & 0.16 & 0.820 \\
\hline \multirow{2}{*}{ Toothpaste of extract of } & Week 1-2 & 1.45 & 2.20 & -0.75 & 0.089 \\
rosella flower 10\% & Week 1-3 & 1.45 & 2.35 & -0.89 & 0.224 \\
& Week 1-4 & 1.45 & 1.66 & -0.21 & 0.661 \\
\hline \multirow{3}{*}{ Control } & Week 1-2 & 1.25 & 1.25 & 0.00 & 1.000 \\
& Week 1-3 & 1.25 & 1.41 & 0.16 & 0.157 \\
& Week 1-4 & 1.25 & 1.56 & 0.31 & 0,102 \\
\hline
\end{tabular}

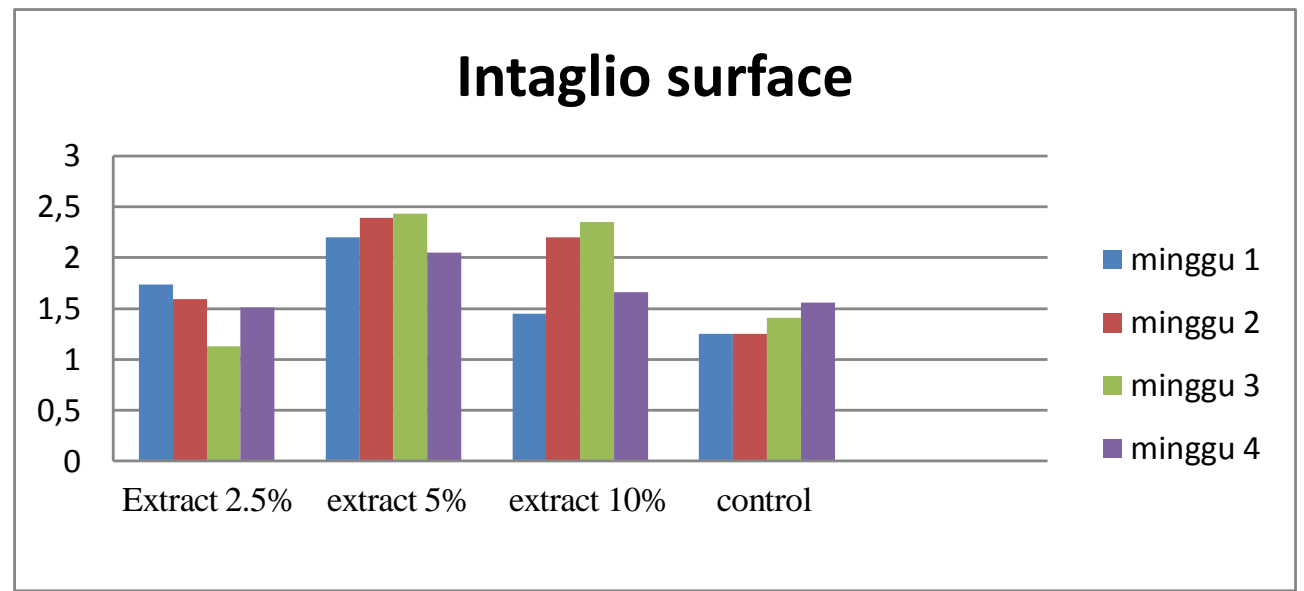

Figure 2 Color changes on intaglio surface color in the $1^{\text {st }}-4^{\text {th }}$ week using toothpaste of extract of rosella flower paste at concentrations of $2.5 \%, 5 \%, 10 \%$, and control.

The antifungal and antibacterial effects produced by rosella calyx in this study were probably caused by rosella calyx (Hibicscus sabdariffa $L$ ) contain several flavonoid compounds that is anthocyanin, gossypeptin3-glucoside, flavonol glucoside hibiscritin, flavonoid gossypeptin, delphinidine cogidine 3-monoglycine-monoglycine-monog lycine-monoglycinemonoglycine-3-glucoside onoglucoside; vitamin $\mathrm{C}$, protein, carbohydrates, beta-carotene and antioxidants. It is expected that besides being a denture cleaner, it should also not cause discoloration on the acrylic denture base. The principle of measurement in this study is to see whether there is a change on the color of acrylic denture base due to use of rosella flower extract.

Color changes can be assessed using the CIELab System which is a color model designed to resemble the perception of human vision using three components, namely $L^{*}$ as luminance or the lighting, and $a^{*}$ and $b^{*}$ as opposite color dimensions. The design of this application system uses the CIELab system. This color model was chosen because it was proven to provide better results than the RGB color model in measuring the similarity of color traits in the image. The $L{ }^{*} a{ }^{*} b$ * color model can also be used to make more accurate color balance corrections and to adjust the contrast of lighting that is difficult and impossible for RGB color models. ${ }^{8}$

In the comparison of color change extract concentration of $5 \%$ and $10 \%$ on the polished and intabglio surfaces, it shows the intaglio surface is more likely to change color than the polished surface. This is in line with the statement that rough surfaces or shafts can affect the stability of acrylic color because it can cause more water absorption and food coloring. ${ }^{9}$ Po- 
rosity can result from evaporation of unreacted monomers and low molecular weight polymers, when the resin temperature reach or exceed the boiling point of the material, but this type of porosity does not occur uniformly along the affected resin segment. ${ }^{8}$

The existence of this insignificant color change could have been due to the contact time was not enough so that the natural dyes in rosella flower extract toothpaste, namely anthocyanin pigment, had not diffused into acrylic and caused significant color changes in acrylic resins. ${ }^{1}$ This anthocyanin pigment is one of the pigments contained in the extract of rosella flower petals and this pigment gives the extract a red color. The stability of this pigment depends on the $\mathrm{pH}$ of the pigment; it is more stable under acidic conditions or at low $\mathrm{pH}$ conditions. The level of degradation of anthocyanin pigments increases as the temperature rises. Thermal degradation causes loss of anthocyanin pigment which is present in rosella flower extract. $^{8}$

According to Anusavice, the color changes that occur in the resin can vary, that is caused by several factors, including the sample size, microporosity of the sample and the length of contact between materials. The wider the sample size, the greater the physical changes in the material can occur. Microporosity determines the occurrence of porous regional color particles. The more porosity the accumulation of dyes absorbed through the diffusion process will also increase. ${ }^{9}$

Ingredients that cause discoloration on a denture basis include synthetic or natural dyes or substances that can be obtained from food and beverages. Discoloration in acrylic is not only caused by the use of rosella flower toothpaste but also because of the daily food and drinks consumed by denture users such as tea, coffee, cola drinks changes the acrylic color to darker. This is due to the accumulation of color pigments attached on the surface and the absorption of particles adhesion that enters the pores of acrylic resin, so that the color absorbed is more than the color that is reflected. Researchers urge patients who are sampled not to consume foods and drinks that cause research to be ambiguous, but if the patient has difficulty carrying it out, then they can remove the denture when taking it. ${ }^{10}$

It was concluded that toothpaste of rosella flower extract does not cause discoloration on the base acrylic denture and there is a color difference between the intaglio and polished surface of the denture base after the use of rosella flower extract toothpaste.

\section{REFERENCES}

1. Depkes RI. Petunjuk pemeliharaan kesehatan gigi dan mulut keluarga. Jakarta; 2000. p. 1-15.

2. Haryanto AG. Terminology dalam ilmu geligi tiruan sebagian lepasan. Jakarta: Hipocrates; 1991. p.12

3. The Internat Journal of Geriatic and Geriontology 2010; 6(1): 8-15

4. Shibata N, Suzuki A, Kobayashi H, Okawa Y. Chemical structure of the cell-wall mannan of Candida albicans serotype-A and its difference in yeast and hyphal Forms. Biochem J 2007: 365-72.

5. Pannuti M. Clinical effect of an herbal dentifrice on the control of plaque and gingivitis. Pesqui Odontol Braz 2011: 323-33.

6. Tanjong A. Pengaruh konsentrasi ekstrak bunga rosella (Hibiscus sabdarifa L) terhadap koloni Candida albicans yang terdapat pada plat gigitiruan. [skripsi] 2011.p.52.

7. Maruapey AM. Penggunaan pasta pembersih gigitiruan bunga Rosella (Hibiscus sabdariffa L.) dalam menghambat pertumbuhan bakteri dan Candida albicans pada gigitiruan. [tesis]. Makassar: Universitas Hasanuddin; 2013.p.57

8. Optel Vision. Definition of Cielab color space. [serial online] 2011; 1-2: [internet]. Available from: RL:http://www.optelvision.com/documents/optel-vision-explanation-on-cielab-color-space.pdf. Diakses 12 desember 2012.

9. Anusavice KJ. Sifat kimia resin sintetik. Dalam: Buku ajar ilmu kedokteran gigi. Ed.10. Alih Bahasa Budiman JA. Jakarta: EGC; 2004. hal. 176-96.

10.Lestari WA. Pengaruh lama perendaman plat gigitiruan akrilik dalam ekstrak bunga Rosella terhadap kekuatan transversa plat gigitiruan. [skripsi] Makassar: Universitas Hasanuddin; 2013. p. 47 